\title{
Regulation of Neurotransmission in the Arcuate Nucleus of the Rat by Different Neuropeptide Y Receptors
}

\author{
Hyewhon Rhim, Gregory A. Kinney, Paul J. Emmerson, and Richard J. Miller \\ Department of Pharmacological and Physiological Sciences, University of Chicago, Chicago, Illinois 60637
}

We examined the effects of peptides of the neuropeptide $Y$ (NPY)/pancreatic polypeptide (PP) family on synaptic transmission in the arcuate nucleus in rat hypothalamic slices. Application of NPY produced two effects. In some cells NPY produced an outward current that had the properties of a $\mathrm{K}^{+}$current. NPY also inhibited the evoked glutamatergic EPSC recorded in these arcuate neurons by a presynaptic mechanism. Although the effects of NPY on the $\mathrm{K}^{+}$current reversed within a few minutes of washout of the peptide, its effects on the EPSC frequently were longer lasting ( $>30 \mathrm{~min}$ ). Similar effects were observed using peptide $\mathrm{YY}$ or the NPY analog [ $\left[\mathrm{Leu}^{31}\right.$, Pro $\left.^{34}\right]$ NPY. Although $\mathrm{K}^{+}$current activation by $\left[\mathrm{Leu}^{31}\right.$,Pro $\left.{ }^{34}\right] \mathrm{NPY}$ was blocked by the selective $\mathrm{Y} 1$ antagonist BIBP 3226 , inhibition of the EPSC was blocked only partially. Other NPY-related peptides such as NPY(13-36), PP, and [D-Trp ${ }^{32}$ ]NPY also inhibited the EPSC. However, none of these peptides produced activation of the $\mathrm{K}^{+}$current. Thus, activation of more than one NPY receptor produces synaptic inhibition in the arcuate nucleus. A Y1 receptor activates a $\mathrm{K}^{+}$current postsynaptically, and several receptor types appear to inhibit the EPSC by a presynaptic mechanism.

Key words: neuropeptide $Y$; neuropeptide $Y$ receptors; arcuate nucleus; hypothalamus
Neuropeptide Y (NPY) is a 36 amino acid peptide that is very widely distributed in the CNS and PNS (Colmers and Wahlestedt, 1993). Administration of NPY directly into the CNS produces a host of effects, consistent with its extensive distribution. These effects include cardiovascular, neuroendocrine, and hyperphagic actions (Colmers and Wahlestedt, 1993; Hendry, 1993; Colmers and Bleakman, 1994; Grundemar and Hakanson, 1994; Larhammer, 1996). Furthermore, NPY-deficient mice show a tendency to exhibit seizures (Erickson et al. 1996a), consistent with a possible role for NPY in the control of hippocampal excitability (Colmers et al., 1988; Bleakman et al., 1993; Colmers and Bleakman, 1994).

It is now known that NPY produces its effects through the activation of at least six receptors (Grundemar et al., 1991b; Herzog et al., 1992; Colmers and Bleakman, 1994; Grundemar and Hakanson, 1994; Bard et al., 1995; Gerald et al., 1995, 1996; $\mathrm{Hu}$ et al., 1996; Weinberg et al., 1996). Activation of these G-protein-linked receptors leads to various signal transduction events that might potentially produce alterations in neuronal activity. For example, NPY has been shown to inhibit adenylate cyclase and voltage-sensitive $\mathrm{Ca}^{2+}$ channels and to activate phospholipase C in a number of cell types (Perney and Miller, 1989; Shigeri and Fujimoto, 1992; Foucart et al., 1993). Furthermore, cloned NPY receptors can produce all of these effects in heterologous expression systems (Herzog et al., 1992; Bard et al., 1995; Gerald et al., 1995, 1996; Sun et al., 1996), and in addition can also produce activation of $\mathrm{G}$-protein gated inwardly rectifying $\mathrm{K}^{+}$ (GIRK) conductances (Brown et al., 1995; Rimland et al., 1996;

Received Jan. 3, 1997; revised Feb. 12, 1997; accepted Feb. 17, 1997.

This work was supported by Public Health Service Grants DA02121, DA02575, MH40165, NS33502, DK42086, and DK44840, and National Institute on Drug Abuse Grant DA07255 (P.J.E.). We thank Drs. Mary Walker and Theresa Branchek for helpful discussions.

Correspondence should be addressed to Dr. Richard J. Miller, Department of Pharmacological and Physiological Sciences, 947 E. 58th Street, MC 0926, Chicago, Illinois 60637.

Copyright (C) 1997 Society for Neuroscience $\quad 0270-6474 / 97 / 172980-10 \$ 05.00 / 0$
Sun et al., 1996). However, there is only one report of this latter type of response to NPY in neurons-in the frog sympathetic nervous system (Zidichouski et al., 1990). No responses of this type have ever been reported in the CNS.

Injections of small amounts of NPY into the brain stimulate food intake quite prodigiously (Kalra and Kalra, 1996; Miller and Bell, 1996). It appears that these effects are mediated by NPY receptors in the hypothalamus. Precisely which subtype or subtypes of NPY receptors are involved in this response is still unclear, although recent evidence suggests that the Y5 receptor plays a major role in the rat (Gerald et al., 1996; Kalra and Kalra, 1996; Matos et al., 1996; Miller and Bell, 1996).

It is believed that NPY-containing neurons, which project from the arcuate nucleus to the paraventricular nucleus and also send collaterals back into the arcuate, may normally play an important role in the control of feeding behavior and in neuroendocrine regulation (Meister et al., 1989; Erickson et al., 1996a,b; Kalra and Kalra, 1996; Miller and Bell, 1996). These neurons may participate in a negative feedback "lipostat" arrangement whereby they are inhibited by leptin, a cytokine secreted from adipose tissue that inhibits food intake (Stephens et al., 1995; Erickson et al., 1996a,b; Glaum et al., 1996; Miller and Bell, 1996). It is also interesting to note that many of the effects of NPY are of extremely long duration, lasting for extensive periods, even after a single intracerebroventricular injection. These include its well known hyperphagic as well as some of its neuroendocrine and cardiovascular effects (Grundemar et al., 1991a; Huhman and Albers, 1994; Kalra and Kalra, 1996). We have now further investigated the actions of NPY within the arcuate nucleus, with the goal of determining the types of NPY receptors involved and the mechanisms by which its effects are produced.

\section{MATERIALS AND METHODS}

Preparation of brain slices. The methods for the preparation of thin brain slices were similar to those described previously (Glaum et al., 1994). Experiments were conducted on Sprague Dawley rats of either sex, aged 
A

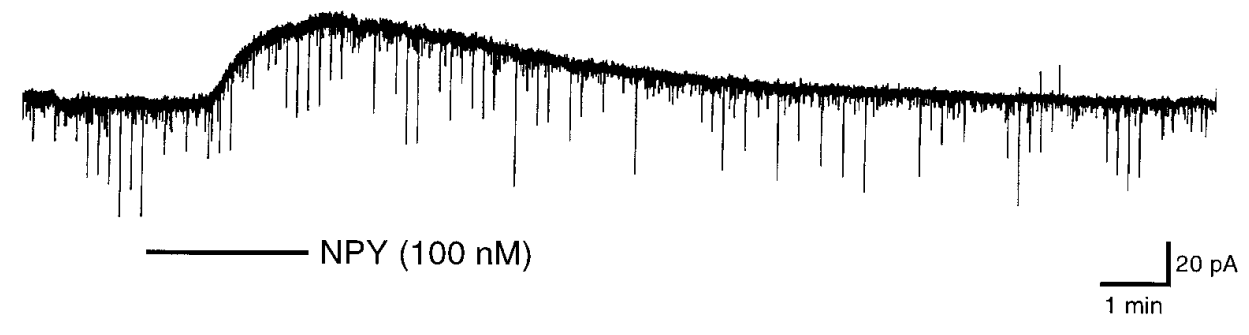

B

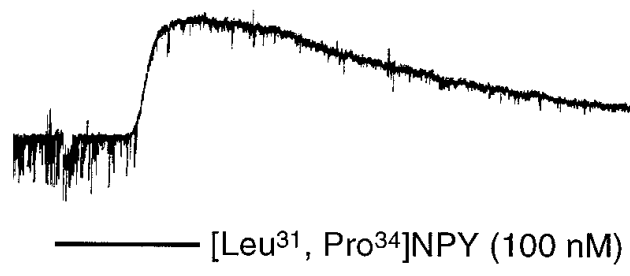

Figure 1. Application of NPY and $\left[\mathrm{Leu}^{31}, \mathrm{Pro}^{34}\right] \mathrm{NPY}$ activated an outward current in a population of arcuate nucleus neurons. $A$, Application of $100 \mathrm{~nm}$ NPY to an arcuate nucleus neuron produced an outward current that readily reversed after washout of the peptide. $B$, Application of $100 \mathrm{~nm}\left[\mathrm{Leu}^{31}\right.$, Pro $^{34}$ ]NPY also produced a reversible outward current in arcuate nucleus neurons. Traces are scanned images from a chart recording taken from the experiment. Downward deflections represent synaptically evoked currents $(0.1 \mathrm{~Hz})$ (A) or spontaneous synaptic currents $(B)$ and illustrate the relative irreversibility of the effects of $\left[\mathrm{Leu}^{31}, \mathrm{Pro}^{34}\right]$ NPY on these currents, compared with its effects on activating the outward current (see text).
10-25 d postnatal. Animals were anesthetized with ether by inhalation and killed by decapitation using a guillotine. The brain was removed rapidly by dissection and placed in chilled $\left(0-6^{\circ} \mathrm{C}\right)$ extracellular solution of the following composition (in $\mathrm{mM}$ ): $126 \mathrm{NaCl}, 3.3 \mathrm{KCl}, 2.5 \mathrm{CaCl}_{2}, 1.3$ $\mathrm{MgSO}_{4}, 1.25 \mathrm{NaH}_{2} \mathrm{PO}_{4}, 26 \mathrm{NaHCO}_{3}$, and $10 \mathrm{D}$-glucose (gassed with $95 \%$ $\mathrm{O}_{2} / 5 \% \mathrm{CO}_{2}, \mathrm{pH} 7.4$; osmolarity $\left.=310 \mathrm{mOsm}\right)$. Thin $(175-200 \mu \mathrm{m}$ thick $)$ coronal slices of the arcuate nucleus of the hypothalamus were cut using a vibrating tissue chopper (Vibratome). Slices were maintained at $30-$ $32^{\circ} \mathrm{C}$ until needed for recording.

For recording, slices were transferred to a submersion chamber mounted on the stage of an upright microscope (Leitz Laborlux) and viewed with a Zeiss $40 \times$ water immersion objective (Thornwood, NY) with Hoffman Contrast Optics. The slices were perfused continuously throughout the experiment with extracellular solution at room temperature $\left(20-25^{\circ} \mathrm{C}\right)$. All recordings were made from visually identified neurons located in the arcuate nucleus. The area of the arcuate nucleus is rich in NPY-positive neuronal cell bodies.

Patch-clamp recording and synaptic stimulation. Patch-clamp recording pipettes were made from thin-walled borosilicate glass capillaries (DC resistance $=3-8 \mathrm{M} \Omega$ when filled with internal solution) using a FlamingBrown horizontal pipette puller (Sutter Instruments, Novato, CA). In all experiments, electrodes were filled with internal solution of the following composition, (in mM): 145 potassium gluconate, $2 \mathrm{MgCl}_{2}, 5 \mathrm{~K}_{2} \mathrm{ATP}, 1.1$ EGTA, $0.1 \mathrm{CaCl}_{2}$, and 5 HEPES, $\mathrm{pH}=7.2$ (osmolarity adjusted to 280-290 mOsm). Patch recording pipettes were mounted in the headstage attached to a stage-mounted three-way hydraulic micromanipulator (Narishige, Tokyo, Japan) and were positioned over the somas of neurons under visual control. Conventional methods for obtaining whole-cell recordings from thin slices (Hamill et al., 1981; Edwards et al., 1989) were used. After the attainment of cell access, transmembrane voltage and current were recorded using an Axoclamp 2B (Axon Instruments, Foster City, CA) amplifier (filtered at $10 \mathrm{kHz}$ ) in the discontinuous voltageclamp mode, stored on computer (Gateway 2000) and via chart recorder (Gould, Glen Burnie, MD), and analyzed using Whole-Cell Patch (Strathclyde Electrophysiology Software).

Bipolar tungsten stimulating electrodes were placed lateral to the arcuate nucleus to activate inputs to arcuate nucleus neurons. In all experiments, stimuli of between 50 and $500 \mu \mathrm{sec}$ were used to elicit a synaptic response, which were maintained at a frequency of $0.1 \mathrm{~Hz}$ to record the time-dependent effects of drug perfusion. For the purposes of data analysis, 2-3 min of evoked EPSCs were averaged (12-18 EPSCs), and the peak of the averaged EPSC was measured. Cells that responded to drug application with a $20 \%$ or greater reduction (a change greater than the $99 \%$ confidence limits of the control window mean) were considered to have responded positively.

Recording and analysis of miniature EPSCs (mEPSCs). mEPSCs were recorded from arcuate nucleus neurons at a holding potential of -60 to $-80 \mathrm{mV}$ in the presence of $1 \mu \mathrm{M} \mathrm{TTX}, 20 \mu \mathrm{M}$ 7-chlorokynurenic acid, and
$10 \mu \mathrm{M}$ bicuculline to pharmacologically isolate AMPA receptor-mediated mEPSCs. [Leu $\left.{ }^{31}, \mathrm{Pro}^{34}\right] \mathrm{NPY}(100 \mathrm{nM})$ was used as the NPY receptor agonist in all of these experiments. All drugs were allowed to equilibrate for at least $5 \mathrm{~min}$ before the onset of recording. Data were sampled continuously at $10 \mathrm{kHz}$ during the recording period, filtered at $1-2 \mathrm{kHz}$, and acquired to disc using pClamp software (Axon Instruments). Cells were periodically monitored for changes in access resistance, and cells that exhibited any significant $(>15 \%)$ changes during the recording period were rejected.

mEPSCs were analyzed using pClamp software. All events were examined visually and accepted or rejected based on subjective visual criteria as well as the objective criteria of amplitude, rise time, and decay time. Events that had an amplitude of $>3 \mathrm{pA}$, rise times of between $200 \mu \mathrm{sec}$ and $3 \mathrm{msec}$, and decay times of between 1 and $30 \mathrm{msec}$ were included in the analysis.

Analyzed data from a 3-5 min recording period (100-600 events) were examined and analyzed further using Prism (Graph Pad, San Diego, CA) and Statmost (Datamost). Cumulative probability plots were constructed

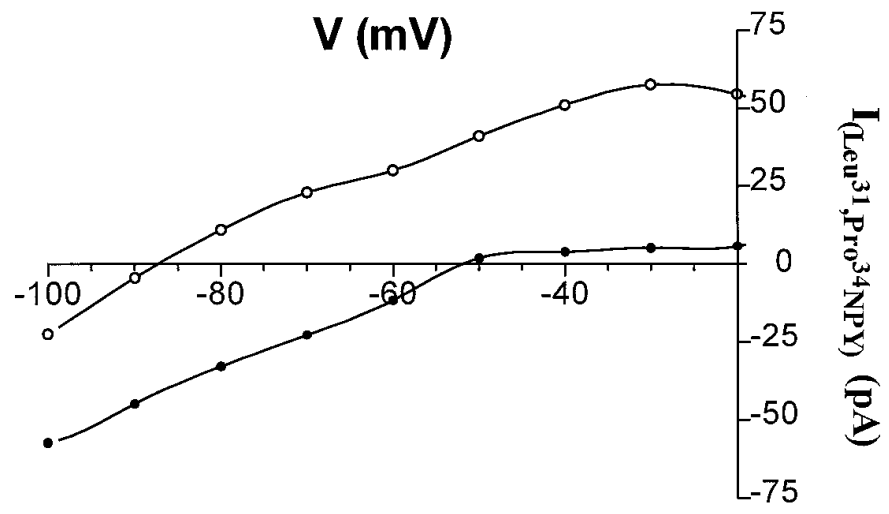

Figure 2. High $\mathrm{K}^{+}$containing external medium caused a shift in the reversal potential of the outward current induced by $100 \mathrm{~nm}$ $\left[\mathrm{Leu}^{31}, \mathrm{Pro}^{34}\right] \mathrm{NPY}$. [ $\left[\mathrm{Leu}^{31}, \mathrm{Pro}^{34}\right] \mathrm{NPY}$-activated currents were examined in this arcuate nucleus neuron at both normal $(3.3 \mathrm{~mm}$, open circles $)$ and high $\left(9.5 \mathrm{mM}\right.$, closed circles) external $\mathrm{K}^{+}$in the presence of $1 \mu \mathrm{M}$ TTX. Data points represent the difference of the current required to clamp the cell at potentials from -20 to $-100 \mathrm{mV}$ in the absence and presence of $\left[\mathrm{Leu}^{31}, \mathrm{Pro}^{34}\right]$ NPY. The shift in the reversal potential of the $\left[\mathrm{Leu}^{31}\right.$, Pro $\left.^{34}\right]$ NPY-activated current in normal external $\mathrm{K}^{+}(-87 \mathrm{mV})$ and high external $\mathrm{K}^{+}(-52 \mathrm{mV})$ was consistent with the calculated change for the Nernst $\mathrm{K}^{+}$reversal potential $(28.2 \mathrm{mV})$. 


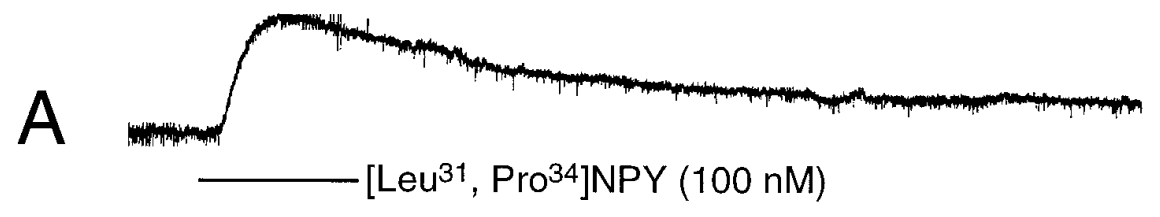

Figure 3. BIBP 3226 inhibited the activation of the outward current $\left[\mathrm{Leu}^{31}{ }^{31}\right.$ Pro $\left.^{34}\right]$ NPY. A, Top trace, Application of $100 \mathrm{~nm}\left[\mathrm{Leu}^{31}, \mathrm{Pro}^{34}\right] \mathrm{NPY}$ induced an outward current in an arcuate nucleus neuron. Middle trace, Preapplication of the selective Y1 antagonist BIBP 3226 to the same cell as in the top trace blocked the outward current produced by $\left[\mathrm{Leu}^{31}, \mathrm{Pro}^{34}\right]$ NPY. Bottom trace, After washout of BIBP 3226 (18 min), an outward current was observed again after application of $\left[\mathrm{Leu}^{31}, \mathrm{Pro}^{34}\right]$ NPY. $B$, In a different cell, application of BIBP 3226 during an outward current induced by $100 \mathrm{~nm}\left[\mathrm{Leu}^{31}, \mathrm{Pro}^{34}\right] \mathrm{NPY}$ immediately reversed the actions of the peptide. Note that the effects of $\left[\mathrm{Leu}^{31}{ }^{3} \mathrm{Pro}^{34}\right]$ NPY on the evoked EPSC were not reversed by BIBP 3226. EPSCs were evoked at a frequency of $0.1 \mathrm{~Hz}$ in all experiments.
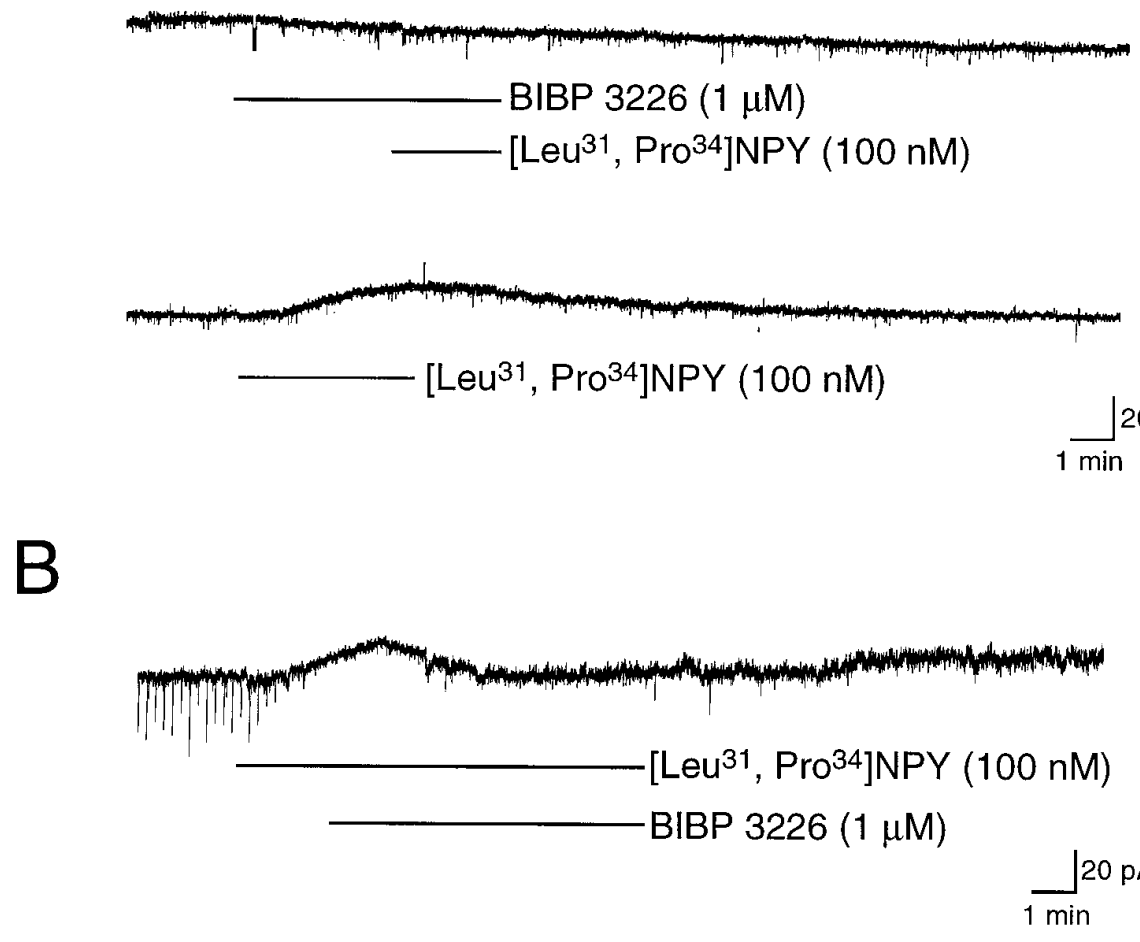

$\underset{1 \min }{\int} 20 \mathrm{pA}$ to visually examine the effects of $\left[\mathrm{Leu}^{31}, \mathrm{Pro}^{34}\right] \mathrm{NPY}$ on the amplitude and interval distributions of mEPSCs, whereas amplitude and interval distributions were compared statistically using a Kolmogorov-Smirnov (K-S) test or a Mann-Whitney $U$ test. Differences in distributions were considered significant if $p<0.05$. Data are expressed in mean \pm SEM.

Application of drugs. Drugs were dissolved in distilled water and applied by bath perfusion. The following compounds were used: bicuculline methiodide (Sigma, St. Louis, MO), D-AP5 (RBI), 7-chlorokynurenic acid (Tocris Cookson, St Louis, MO), TTX (Sigma), human NPY (Sigma and Bachem), NPY-free acid (Bachem, King of Prussia, PA), human $\left[\mathrm{Leu}^{31}\right.$, Pro $\left.^{34}\right]$ NPY (Sigma), human PYY (Bachem), porcine NPY 13-36 (Sigma), rat PP (Sigma), and BIBP 3226, which was the generous gift of Mary Walker, Synaptic Pharmaceuticals. Drugs were applied for 5-10 min to obtain a steady-state bath concentration.

\section{RESULTS}

Whole-cell patch recordings were obtained from 311 neurons in $\sim 133$ preparations of $175-200-\mu \mathrm{m}$-thick coronal slices of rat arcuate nucleus. Unless otherwise noted, all experiments were performed at a holding potential of -60 or $-70 \mathrm{mV}$ in the presence of bicuculline $(10 \mu \mathrm{M})$, D-AP5 $(10 \mu \mathrm{M})$, and $1.5 \mathrm{mM}$ external $\mathrm{Mg}^{2+}$ to pharmacologically isolate the AMPA receptor-mediated EPSC (Glaum et al., 1996).

\section{Postsynaptic effects of NPY}

NPY (100 nM) activated an outward current $(22.0 \pm 7.7$ pA, 6 of 23 cells) in a population of neurons from which recordings were made (Fig. 1A). After washout of the peptide, the current relaxed back to the original baseline over a period of $10-15 \mathrm{~min}$. The "Y1" selective NPY agonist [Leu ${ }^{31}$, Pro $^{34}$ ]NPY (100 nM) produced effects that appeared identical to those observed with NPY (26.7 $\pm 5.1 \mathrm{pA}, 9$ of 44 cells), suggesting that the NPY response was produced, at least in part, by activation of Y1 receptors (Fig. $1 B)$. The current, which exhibited inward rectification, reversed at $-84.0 \pm 3.0 \mathrm{mV}(n=6)$ in normal solutions $\left(\mathrm{K}_{\mathrm{o}}=3.3 \mathrm{mM}\right)$, consistent with the idea that it was caused by the activation of a $\mathrm{K}^{+}$conductance. The reversal potential shifted to $-50.4 \pm 4.6$ $\mathrm{mV}(n=6)$ when the external $\mathrm{K}^{+}$was raised to $9.5 \mathrm{~mm}$, consistent with a shift in the Nernst equilibrium potential for $\mathrm{K}^{+}$of $28.2 \mathrm{mV}$ and further supporting the contention that $\left[\mathrm{Leu}^{31}, \mathrm{Pro}^{34}\right] \mathrm{NPY}$ directly activated $\mathrm{a} \mathrm{K}^{+}$conductance postsynaptically (Fig. 2). Inclusion of $\mathrm{Ba}^{2+}$ in the perfusate blocked the $\left[\mathrm{Leu}^{31}, \mathrm{Pro}^{34}\right] \mathrm{NPY}$ activated current. In three cells, $\left[\mathrm{Leu}^{31}, \mathrm{Pro}^{34}\right] \mathrm{NPY}$ activated a current of $17.1 \pm 6.8 \mathrm{pA}$, which was blocked completely by $100 \mu \mathrm{M}$ $\mathrm{Ba}^{2+}(108 \pm 12 \%, n=3)$ (data not shown). This block by $\mathrm{Ba}^{2+}$ further supports the idea that $\left[\mathrm{Leu}^{31}, \mathrm{Pro}^{34}\right] \mathrm{NPY}$ activated a $\mathrm{K}^{+}$ current.

These postsynaptic effects of $\left[\mathrm{Leu}^{31}, \mathrm{Pro}^{34}\right] \mathrm{NPY}$ were inhibited by the selective Y1 antagonist BIBP 3226. This was shown in two ways. After observation of a response to [ $\mathrm{Leu}^{31}$, Pro $\left.^{34}\right]$ NPY, addition of BIBP $3226(1 \mu \mathrm{M})$ blocked the effect of a second addition of the peptide (Fig. $3 A ; n=2$ ). That this was not because of desensitization in these instances was shown by partial recovery of the response after washout of the peptide (Fig. $3 A$ ). Second, if BIBP 3226 was added to the slice during a response to $\left[\mathrm{Leu}^{31}, \mathrm{Pro}^{34}\right] \mathrm{NPY}$, the current relaxed back to 
baseline (Fig. $3 B ; n=2$ ). Addition of $100 \mathrm{~nm}$ PYY, which acts as an agonist at multiple subtypes of NPY receptors, including the Y1 subtype, also activated an outward current of similar magnitude $(15.7 \pm 3 \mathrm{pA} ; n=3 / 20)$. In two of these cells, application of NPY before PYY application resulted in an outward current averaging $25 \mathrm{pA}$. The Y2 agonist NPY (13-36) $(100 \mathrm{nM} ; n=20)$, PP $(100 \mathrm{nM} ; n=8)$, the Y5 agonist [D-Trp ${ }^{32}$ ]NPY (100 nM and $500 \mathrm{~nm} ; n=13$ and $n=6$; Gerald et al., 1996), and NPY-free acid (100 nм; $n=10)$ never produced an outward current.

In summary, it appears that activation of a Y1 receptor on a population of arcuate neurons produces activation of an inwardly rectifying $\mathrm{K}^{+}$current. Although this response has not been observed previously as the result of activation of NPY receptors in the brain, it has frequently been observed with a number of G-protein-linked receptors and is also consistent with the ability of $\mathrm{Y} 1$ receptors to activate GIRK-like $\mathrm{K}^{+}$ channels in Xenopus oocytes (Brown et al., 1995; Sun et al., 1996). Activation of other types of NPY receptors does not appear to produce this response.

\section{NPY receptor-mediated synaptic depression}

To examine potential effects of NPY on synaptic transmission, stimulating electrodes were placed ventrolaterally to the arcuate nucleus, and inputs were stimulated at $0.1 \mathrm{~Hz}$ while recording from arcuate neurons. Under the conditions used in these experiments (i.e., in the presence of bicuculline and D-AP5), stimulation of inputs resulted in an EPSC that was completely blocked by AMPA antagonists such as CNQX (Glaum et al., 1996). In many cases (15/23), $100 \mathrm{nM}$ NPY produced a strong inhibition of the EPSC (Fig. 4A). Similar effects were also observed using $\left[\mathrm{Leu}^{31}\right.$,Pro $\left.{ }^{34}\right]$ NPY (100 nM; $\left.n=16 / 28\right)$ (Fig 4B,C; also see Figs. $1 B$ and $3 B)$, PYY (100 nм; $n=16 / 18)$, NPY (13-36) $(100 \mathrm{~nm} ; n=$ 10/20), PP (100 nM; $n=3 / 8)$, and [D-Trp ${ }^{32}$ ]NPY (100 nм; $n=$ 7/13; $500 \mathrm{~nm} ; n=5 / 6$ ) (Fig. $5 A-D$; also see Fig. 6). Also, $100 \mathrm{~nm}$ NPY-free acid was ineffective (Fig. $4 D, E ; n=10$ ). In the latter case, we were able to demonstrate in several instances that in recordings where NPY-free acid was ineffective, subsequent addition of NPY produced a depression of the EPSC (Fig. $4 D ; n=$ $6)$. The lack of effect of NPY-free acid supports the idea that the effects observed with NPY and related peptides are receptormediated. The effects of $\left[\mathrm{Leu}^{31}, \mathrm{Pro}^{34}\right] \mathrm{NPY}$ were potent. The peptide produced a maximal inhibition of $49 \pm 0.2 \%$ of the EPSC, with half-maximal effects occurring at $0.74 \mathrm{~nm}$ (Fig. 7). Of particular interest was the time course of the inhibition observed. The amplitude of the EPSC began to decline rapidly within a few minutes after addition of the peptide. In a few instances, the NPY receptor-mediated depression reversed after washout (Fig. 4C). In many cases, however, the EPSC remained depressed for many minutes after washout of the drug. As illustrated in Figure 4A, $B$, for example, application of both NPY and $\left[\mathrm{Leu}^{31}, \mathrm{Pro}^{34}\right] \mathrm{NPY}$ produced a strong depression of the EPSC that did not wash during the course of the experiment, although in the case of NPY (Fig. $4 A$ ), a slow recovery was evident at $30 \mathrm{~min}$ wash. Such long-lasting depression was observed frequently with all NPY agonists (Fig. $5 A-D$ ). It is unlikely that this was caused by a lack of washout of the agonist, because the activation of the $\mathrm{K}^{+}$ conductance reversed much more rapidly (see above). Indeed, when both phenomena were observed in the same cell, the activation of the outward current could be seen to reverse much more rapidly than the inhibition of the EPSC (e.g., Fig. 1B). It is also unlikely that the observed long-lasting depression was an artifact introduced by a change in access resistance. Access was checked routinely at several points during each experiment, and cells that showed any changes were rejected. Finally, it is unlikely that such long-lasting depression is because of significant rundown of the synaptic current. In several cases, the addition of an agonist had no effect on synaptic transmission. In such cases, these cells were recorded from routinely for up to $60 \mathrm{~min}$ after agonist application, with little observable rundown in the synaptic current (e.g., Fig. $4 E)$. Although a small $(<10 \%)$ degree of rundown was occasionally observed, this could not account for the level of depression that was observed with NPY agonists, nor would it be consistent with the slow washout that was observed in some cells (e.g., Fig. $4 A$ ). It should also be stressed that long-lasting depression of the EPSC was not observed using NPY-free acid, demonstrating further that these effects were not merely attributable to "run down" of the EPSC amplitude.

The inhibition of the EPSC is likely to be a presynaptic effect, as has been reported elsewhere for the actions of NPY on synaptic transmission (see Discussion). Given the observed postsynaptic effects of NPY reported here, however, we thought it possible that some of the effects of NPY on transmission might be of postsynaptic origin (see also van den Pol et al., 1996). To examine the site of action of NPY on synaptic transmission, we examined the effect of $\left[\mathrm{Leu}^{31}, \mathrm{Pro}^{34}\right] \mathrm{NPY}$ on mEPSCs recorded in the presence of TTX. For 5 min before recording, $1 \mu \mathrm{M}$ TTX was applied to ensure complete block of synaptic transmission. Afterward, 5-7 min of control data were acquired. Then $100 \mathrm{~nm}\left[\mathrm{Leu}^{31}, \mathrm{Pro}^{34}\right] \mathrm{NPY}$ was applied. After another 5-min equilibration period, 5-7 $\mathrm{min}$ of data in the presence of $\left[\mathrm{Leu}^{31}, \mathrm{Pro}^{34}\right] \mathrm{NPY}$ were acquired. In six of six cells, $\left[\mathrm{Leu}^{31}, \mathrm{Pro}^{34}\right] \mathrm{NPY}$ had no effect on the amplitude distribution of mEPSCs ( $p>0.05$; 6 of 6 cells; K-S test); however, in one of six cells, $\left[\mathrm{Leu}^{31}, \mathrm{Pro}^{34}\right] \mathrm{NPY}$ caused a significant increase in the interval distribution ( $p<0.005 ; 1$ of 6 cells; $\mathrm{K}-\mathrm{S}$ test). Data from the cell exhibiting a significant change in the interval

Figure 4. NPY and $\left[\mathrm{Leu}^{31}\right.$, $\left.\mathrm{Pro}^{34}\right] \mathrm{NPY}$ caused a depression of AMPA receptor-mediated synaptic transmission in the arcuate nucleus, whereas NPY free-acid had no effect. $A$, Application of $100 \mathrm{~nm}$ NPY caused a depression in the evoked EPSC, as recorded from an arcuate nucleus neuron. After

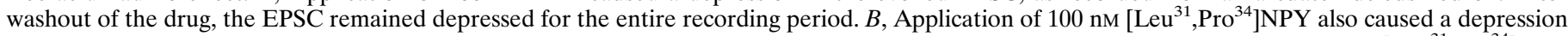
in AMPA receptor-mediated synaptic transmission, an effect that again lasted for the entire recording period. $C$, Application of $100 \mathrm{nM}^{[\mathrm{Leu}}{ }^{31}$,Pro $\left.{ }^{34}\right] \mathrm{NPY}$ to a different cell than in $B$ caused a depression in AMPA receptor-mediated synaptic transmission that readily reversed after washout of the peptide. For $A-C, a$ represents the time course of the effects of NPY and $\left[\mathrm{Leu}^{31}\right.$, Pro $\left.^{34}\right] \mathrm{NPY}$, respectively, on synaptic transmission, whereas $b-d$ are averaged EPSCs taken from the respective cells showing EPSCs before drug application $(b)$, during drug application $(c)$, and after washout of the drug $(d)$. The time at which the averages were taken are indicated in $a . D, E$, NPY-free acid had no effect on synaptic transmission. $a$, Time course plot of the effects of NPY-free acid and NPY on synaptic transmission. Application of $100 \mathrm{nM}$ NPY-free acid had no effect on the evoked synaptic current in $D$ or $E$. In $D$, application of $100 \mathrm{nM}$ NPY after washout of NPY-free acid produced a significant depression of the EPSC, whereas in $E, 100 \mathrm{nM}$ NPY had no effect either. $b-d$, Averaged EPSCs taken from the same cell showing before drug addition $(b)$, during the application of NPY-free acid $(c)$, and during the application of NPY $(d)$. The time during which the averages were taken are indicated in $a$. AMPA receptor-mediated synaptic currents were pharmacologically isolated by including $10 \mu \mathrm{M}$ bicuculline and $10 \mu \mathrm{M}$ D-AP5 in the external bathing medium. 
A

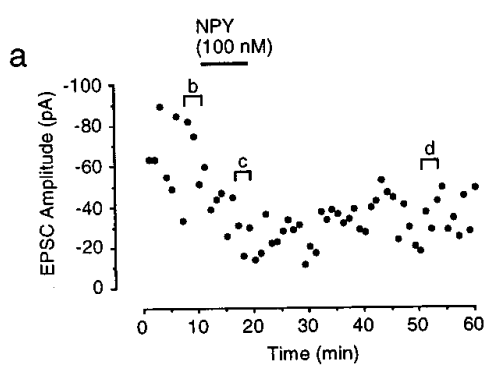

b<smiles>[2H]C1C(C)=C(C)C1CC</smiles>

Control

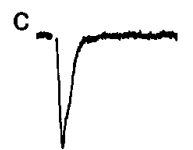

NPY (100nM)

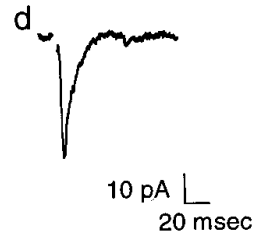

Wash

B

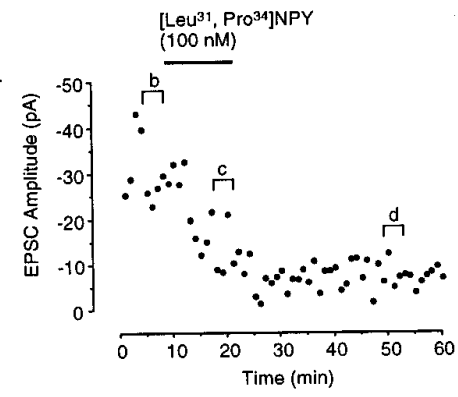

b

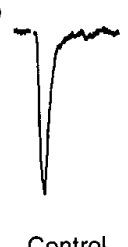

c.
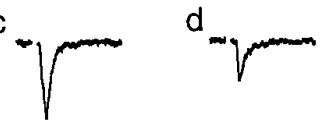

$5 \mathrm{pA} L$

$20 \mathrm{msec}$

Control

$\left[\right.$ Leu $\left.^{31}, \mathrm{Pro}^{34}\right]$ NPY Wash (100 nM)
C

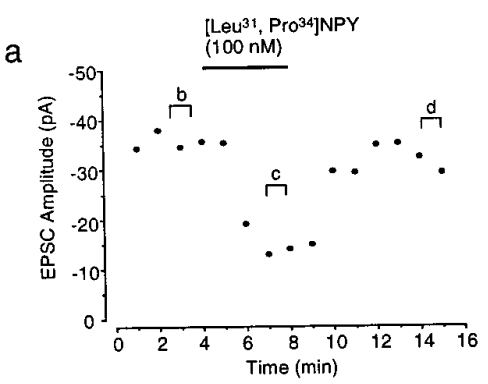

b

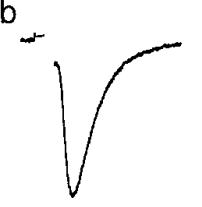

Control c

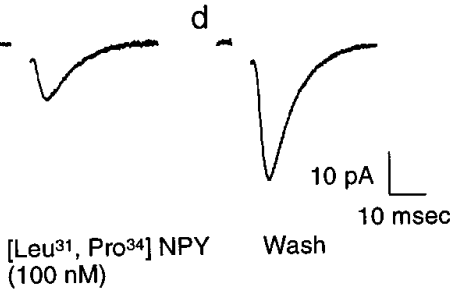

D

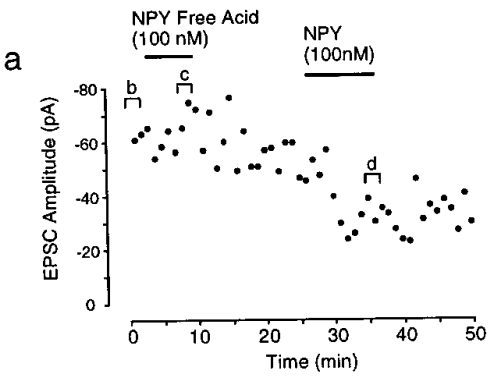

b

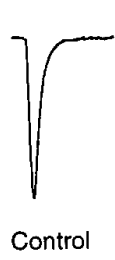

C

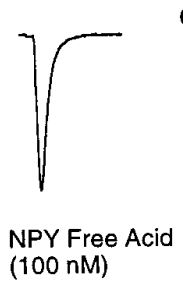

d

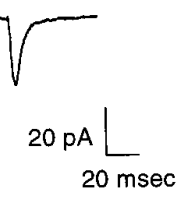

NPY

(100nM)

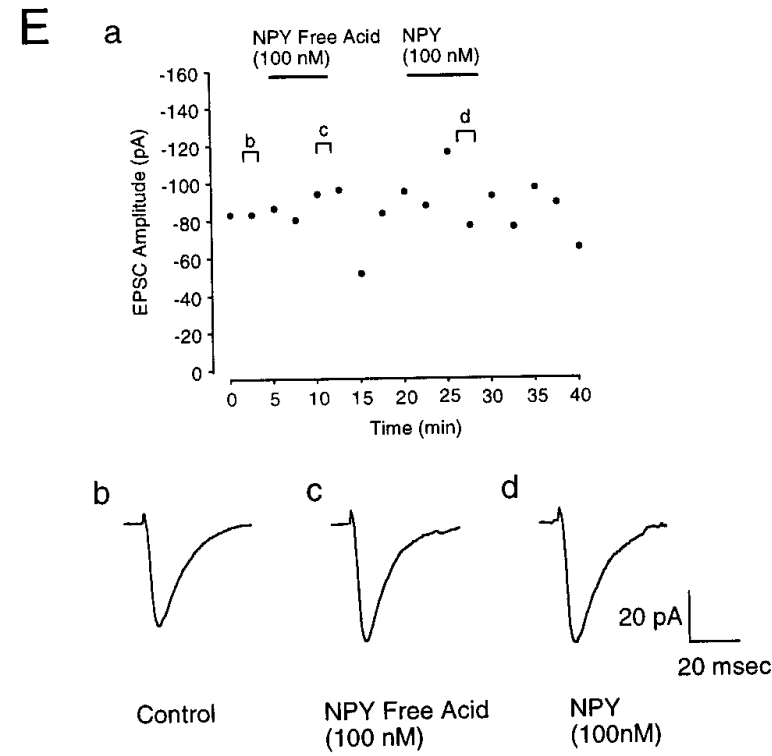



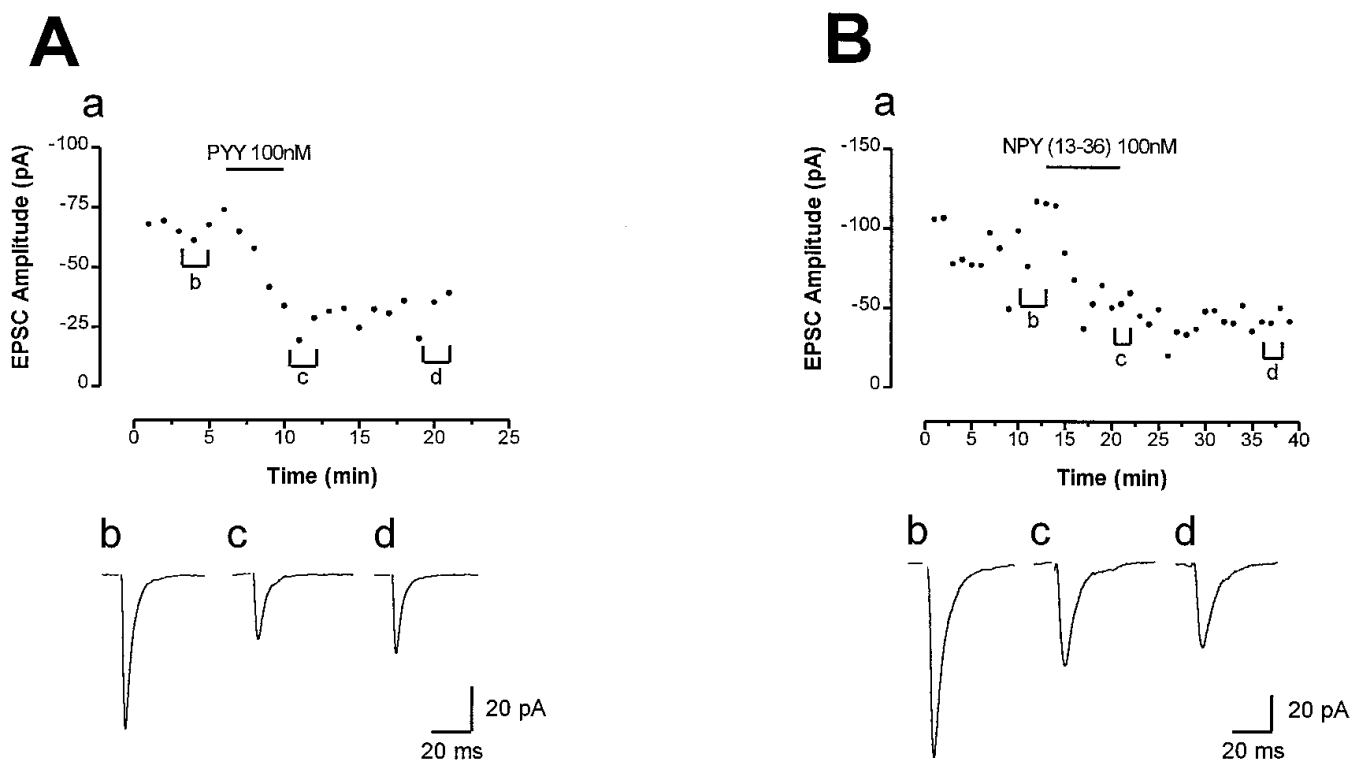

Control + PYY Wash

Control + NPY(13-36) Wash
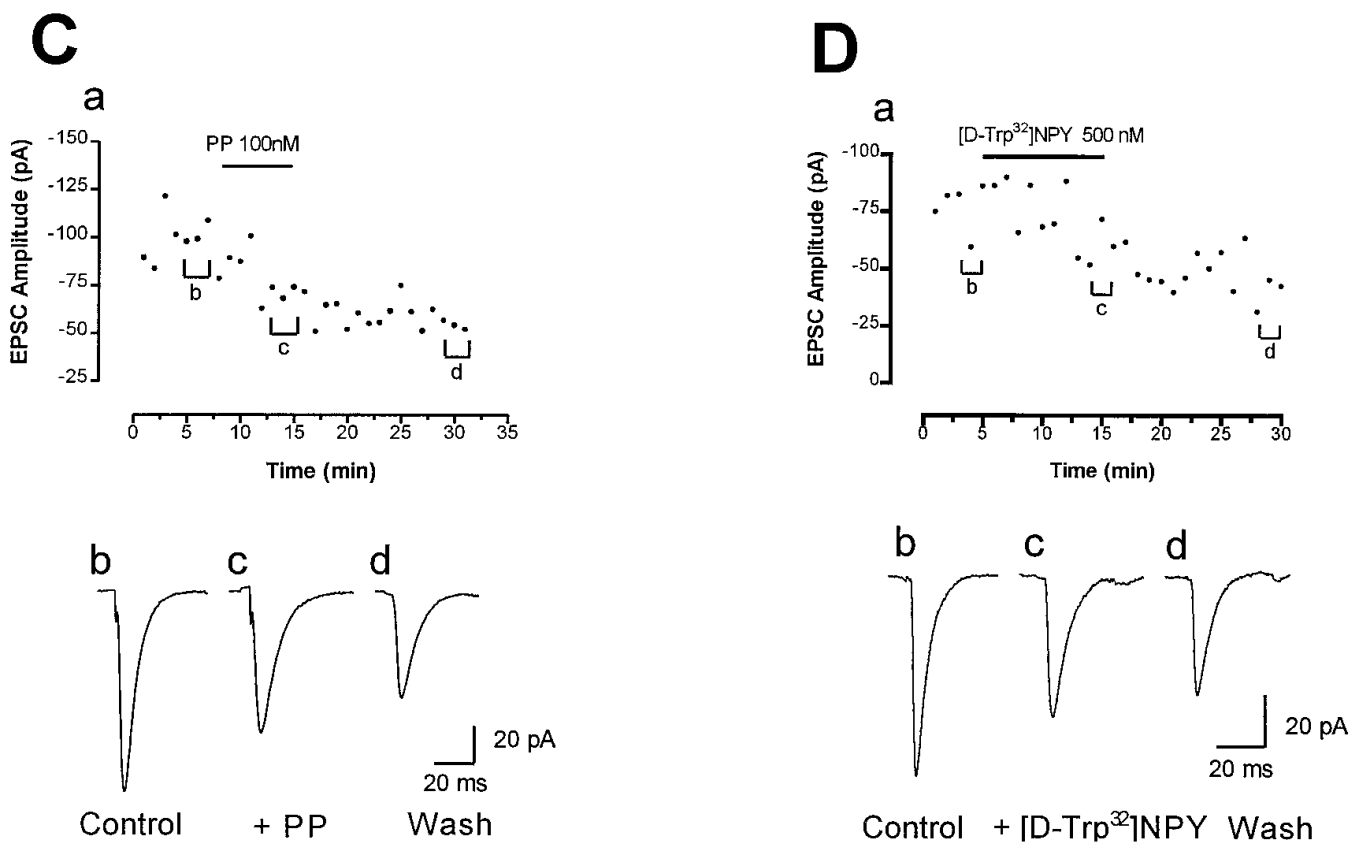

Figure 5. Different NPY receptor agonists induced long-lasting depression of synaptic transmission in the arcuate nucleus. $A-D$, PYY, NPY (13-36), PP, and $\left[\mathrm{D}-\mathrm{Trp}^{32}\right] \mathrm{NPY}$ all caused a depression in AMPA receptor-mediated synaptic transmission in the arcuate nucleus. Each panel $(A-D)$ illustrates the time course $(a)$ of the drug effect as well as sample averages of EPSCs $(b-d)$ taken from the times indicated in the time course plots $(a)$. For other details see Figure 4.

distribution are shown in Figure $8 A, B$. When the data from all six cells were pooled and examined, a significant change in the mean interval of the pooled data was observed $(p<0.01$, Mann-Whitney $U$ test), with no change in the mean amplitude of the pooled data (Fig. $8 C, D$ ). In addition, even when the one cell that showed a significant change was excluded from the pooled data, a significant change was still observed $(p<0.01$, $n=5$; Mann-Whitney $U$ test). This reduction in frequency, coupled with the lack of change in amplitude distribution, is consistent with a solely presynaptic action of NPY on synaptic transmission.

We attempted to see whether the inhibitory effect of $\left[\mathrm{Leu}^{31}, \mathrm{Pro}^{34}\right]$ NPY on the EPSC was also produced by activation of a Y1 receptor. We found that BIBP 3226 was unable to reverse the effects of NPY agonists as it did with the postsynaptic effects of these peptides (Fig. 3B). Depending on the signal transduction system involved, however, this might not necessarily be expected. Thus, we also attempted to see whether addition of BIBP 3226 


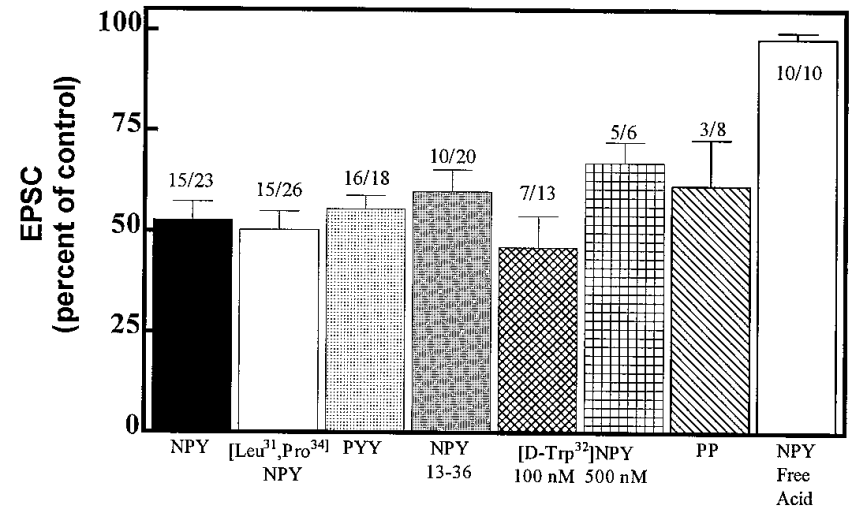

Figure 6. A histogram demonstrating the degree of synaptic depression produced by the various NPY receptor agonists. Bars represent \% control of a population of averaged EPSCs measured in the presence of the respective agonist. Except for NPY-free acid, only cells that responded to the respective agonist were considered in the construction of the histogram (see Materials and Methods). Data represented are means \pm SEM.

before the addition of $\left[\mathrm{Leu}^{31}, \mathrm{Pro}^{34}\right] \mathrm{NPY}$ blocked the inhibitory actions of this peptide (Fig. 9). BIBP $3226(1 \mu \mathrm{M})$ alone had no effect on amplitude of the EPSC $(-1.2 \pm 2.2 \% ; 26$ cells $)$. In some cells it was clear that $\left[\mathrm{Leu}^{31}, \mathrm{Pro}^{34}\right] \mathrm{NPY}$ was ineffective in the presence of the antagonist but subsequently produced effects after its washout $(25.7 \pm 3.7 \%$ inhibition; $7 / 24$ cells) (Fig. $9 A)$. On the other hand, it was also clear that in other cells, $\left[\mathrm{Leu}^{31}, \mathrm{Pro}^{34}\right] \mathrm{NPY}$ was able to decrease the amplitude of the EPSC even in the presence of BIBP 3226 (29.1 $\pm 4.3 \%$ inhibition; 8/25 cells), sometimes producing further inhibition after removal of the antagonist (Fig. 9B). Thus, it appears that a component of the synaptic depression may be caused by an action on Y1 receptors, although other receptors also seem to be involved, and their relative contribution may differ at different synapses.

\section{DISCUSSION}

When the hyperphagic and neuroendocrine actions of NPY are considered, the arcuate nucleus and its connections appear to be of central importance (Stanley, 1993; Kalra and Kalra, 1996; Miller and Bell, 1996). Not only is the arcuate nucleus the source of much of the NPY containing innervation of the PVN, but these neurons also send collaterals back into the arcuate, thereby contributing significantly to the NPY innervation of the arcuate itself (Meister et al., 1989). Regulation of the activity of these neurons may be an important way of regulating food intake. Indeed changes in food intake in many different circumstances are known to be associated with changes in the levels of NPY and NPY-precursor gene expression within the arcuate and PVN (Stanley, 1993). It is clearly of interest, therefore, to define the cellular actions of NPY in this region of the brain. Furthermore, considering that NPY can exert its effects through the activation of a family of different NPY receptors, it is also important to know which of these receptors is responsible for effects mediated by NPY.

Although a considerable amount of data describe the effects and mechanism of action of NPY in the PNS, corresponding data in the CNS are much more limited (Colmers and Bleakman, 1994; Grundemar and Hakanson, 1994). In the PNS, NPY reduces synaptic transmission at a number of sympathetic neuroeffector junctions-an effect that is consistent with the widely reported ability of NPY to inhibit neuronal $\mathrm{Ca}^{2+}$ channels (Toth et al., 1993; Colmers and Bleakman, 1994). Indeed, activation of several

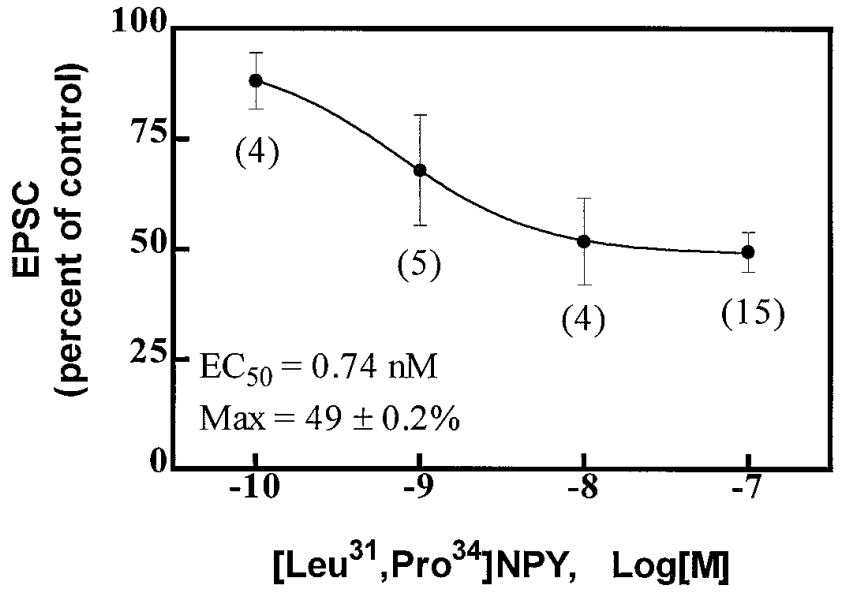

Figure 7. Dose-response curve to $\left[\mathrm{Leu}^{31}{ }^{\text {, Pro }}{ }^{34}\right]$ NPY. Application of progressively higher doses of $\left[\mathrm{Leu}^{31}\right.$, Pro $\left.^{34}\right]$ NPY $(0.1-100 \mathrm{nM})$ resulted in a dose-dependent decrease in the amplitude of evoked synaptic currents, as recorded from arcuate nucleus neurons. The number of observations at each concentration are indicated in brackets below each point. Data are means \pm SEM.

NPY receptors has been shown to inhibit N-type $\mathrm{Ca}^{2+}$ channels in heterologous expression systems (Sun et al., 1996). Activation of NPY receptors in the CNS also suppresses synaptic transmission in a number of brain areas, including the arcuate nucleus (Colmers and Wahlestedt, 1993; Colmers and Bleakman, 1994; Glaum et al., 1996; Obrietan and van den Pol, 1996). Expression of different NPY receptors in frog oocytes also leads to the activation of co-expressed inwardly rectifying $\mathrm{K}^{+}$channels of the GIRK family (Brown et al., 1995; Rimland et al., 1996; Sun et al., 1996) - an effect that is commonly observed with different G-protein-linked neurotransmitter receptors. In spite of these observations, direct activation of $\mathrm{K}^{+}$currents by NPY has not been demonstrated previously in the CNS. However, the experiments reported here clearly demonstrate for the first time that activation of a $\mathrm{K}^{+}$current(s) by NPY can be observed in a population of arcuate neurons.

The $\mathrm{K}^{+}$current response bears many of the hallmarks of a Y1 receptor-mediated effect. Thus, it is mimicked by PYY and $\left[\mathrm{Leu}^{31}, \mathrm{Pro}^{34}\right] \mathrm{NPY}$ and is blocked by BIBP 3226. BIBP 3226 appears to be very selective for Y1 receptors, in so far as its actions on the diverse family of NPY receptors are concerned (Doods et al., 1995; Wieland et al., 1995; Gerald et al., 1996; Sun et al., 1996). Thus, although it has become clear recently that $\left[\mathrm{Leu}^{31}, \mathrm{Pro}^{34}\right] \mathrm{NPY}$ activates several types of NPY receptors in addition to $\mathrm{Y} 1$, including the recently described rat and murine Y5 receptors (Gerald et al., 1996; Weinberg et al., 1996), block by BIBP 3226 has thus far proven to be specific for Y1 receptors (Rudolf et al., 1994; Wieland et al., 1995; Gerald et al., 1996). We also observed that activation of other types of NPY receptors by their relevant "selective" agonists (e.g., PP, NPY 13-36, $\left.\left[\mathrm{D}-\operatorname{Trp}^{32}\right] \mathrm{NPY}\right)$ did not activate a $\mathrm{K}^{+}$current in these arcuate neurons. Thus, it appears that a $\mathrm{Y} 1$ receptor localized on a population of arcuate neurons is responsible for this effect. The fact that other NPY receptors can also activate $\mathrm{K}^{+}$currents in heterologous expression systems suggests, however, that all NPY receptors may also be capable of producing similar responses in other parts of the brain. The reason that such effects have never been observed previously in the CNS may relate to other factors dictating the selectivity of responses activated by G-protein-linked 


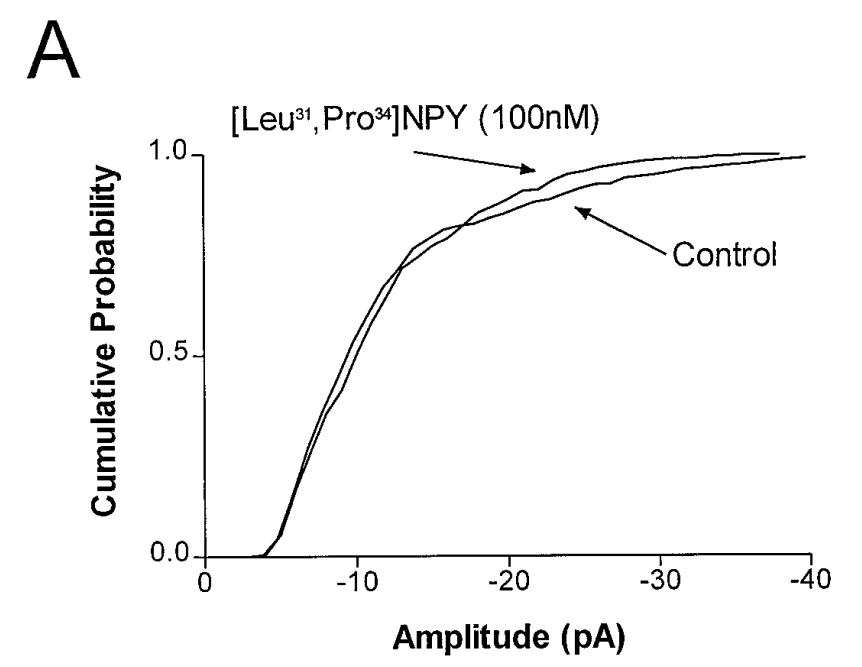

\section{B}
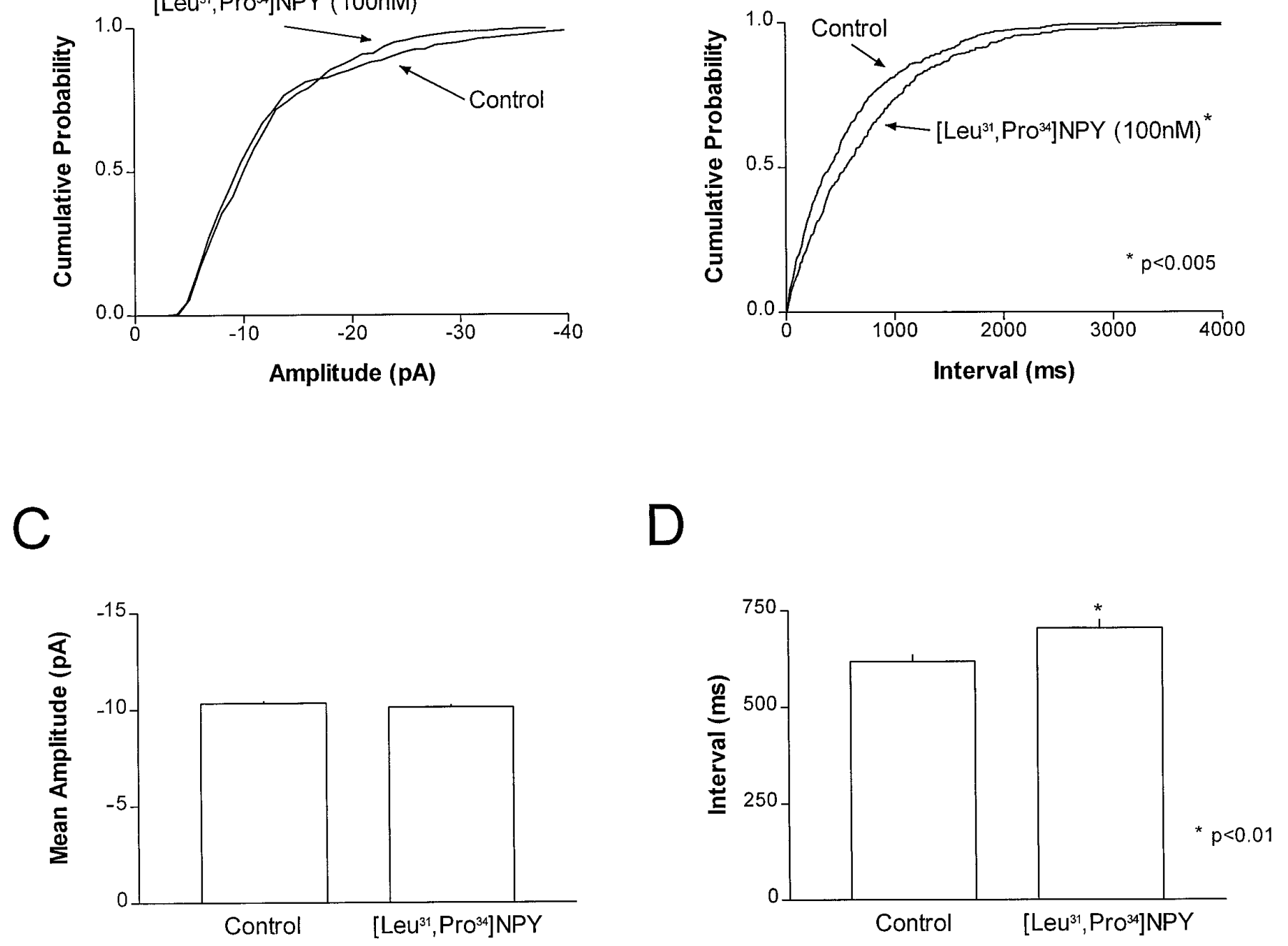

Figure 8. $\left[\mathrm{Leu}^{31}\right.$,Pro $\left.{ }^{34}\right] \mathrm{NPY}$ causes a reduction in the frequency of mEPSCs with no effect on the amplitude distribution. $A, B$, Cumulative probability plots of the distribution of mEPSC amplitudes $(A)$ and intervals $(B)$ for a single cell showing a significant change in the interval distribution $(p<0.005$; $\mathrm{K}-\mathrm{S}$ test). $C, D$, Effect of $\left[\mathrm{Leu}^{31}, \mathrm{Pro}^{34}\right] \mathrm{NPY}$ on the mean amplitude $(C)$ and mean interval $(D)$ for data pooled from six cells. The pooled data showed a significant change in the interval ( $p<0.01$, Mann-Whitney $U$ test), whereas no significant change in the mean amplitude was observed. All data were acquired in the presence of $1 \mu \mathrm{M}$ TTX, $20 \mu \mathrm{M}$ 7-chlorokynurenic acid, and $10 \mu \mathrm{M}$ bicuculline.

receptors (Schreibmayer et al., 1996). It should also be noted that the identity of the $\mathrm{K}^{+}$current(s) activated by NPY in arcuate nucleus neurons remains to be determined precisely.

The synaptic depression produced by NPY receptor activation in the arcuate is more difficult to characterize. We demonstrated previously that NPY could block AMPA receptor-mediated EPSCs and $\mathrm{GABA}_{\mathrm{A}}$ receptor-mediated IPSCs in the arcuate, whereas the cytokine leptin was capable of blocking only EPSCs (Glaum et al., 1996). As we now demonstrate, many of these NPY receptor-mediated effects are extremely long lasting. Such observations appear analogous to those of Obrietan and van den Pol (1996) and van den Pol et al. (1996), who demonstrated that NPY produced a long-lasting suppression of GABAergic transmission in the SCN and also showed that a similarly long-lasting effect seemed to occur with GABAergic transmission in the arcuate (Obrietan and van den Pol, 1996). In addition, van den Pol et al. (1996) recently reported an NPY receptor-mediated long-term depression of excitatory synaptic transmission in the SCN. These observations may provide an electrophysiological correlate to reports of "long-term" effects of NPY in whole-animal studies (Grundemar et al, 1991a; Huhman and Alders 1994). The mechanisms underlying such long-term synaptic depression are unclear; however, the contention that it is caused by a presynaptic inhibition of release is supported by the observation that the frequency of mEPSCs was reduced in the presence of $\left[\mathrm{Leu}^{31}, \mathrm{Pro}^{34}\right] \mathrm{NPY}$, whereas the amplitude distribution remained unchanged. In agreement with these observations, van den Pol et al. (1996) also reported that the frequency of mEPSCs was reduced by application of NPY in the SCN, and McQuiston and Colmers (1996) reported similar effects of NPY in the CA3 region of the hippocampus. Previous studies have demonstrated that NPY suppresses transmitter release at many synapses, primarily through inhibition of $\mathrm{Ca}^{2+}$ channels such as N-type channels (Toth et al., 1993; Colmers and Bleakman, 1994; Chen and van den Pol, 1996; McQuiston et al., 1996). Thus, inhibition of $\mathrm{Ca}^{2+}$ channels could play a role in the observed presynaptic inhibition; however, our 
A

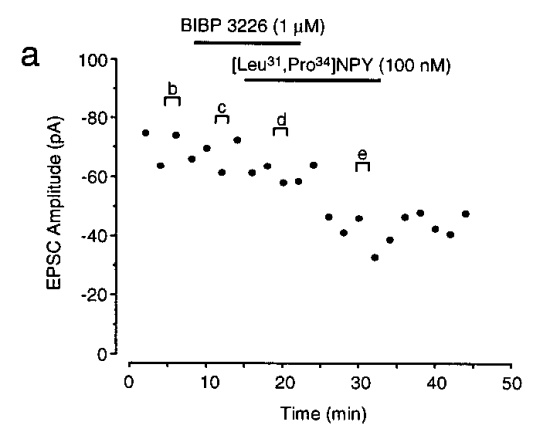

b

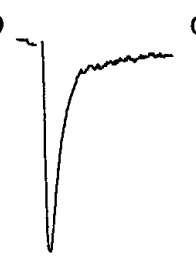

Control

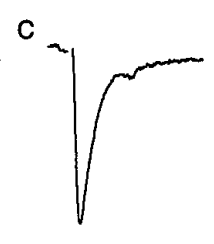

BIBP 3226 d

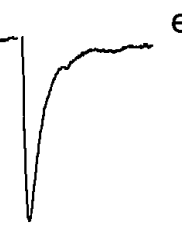

BIBP $3226(1 \mu \mathrm{M})+$ Leu $31, \mathrm{Pro}^{34} \mathrm{NPY}$ (100 nM)

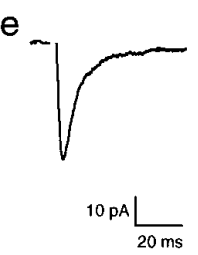
(100 nM)
Leu ${ }^{31}, \mathrm{Pro}^{34} \mathrm{NPY}$

B

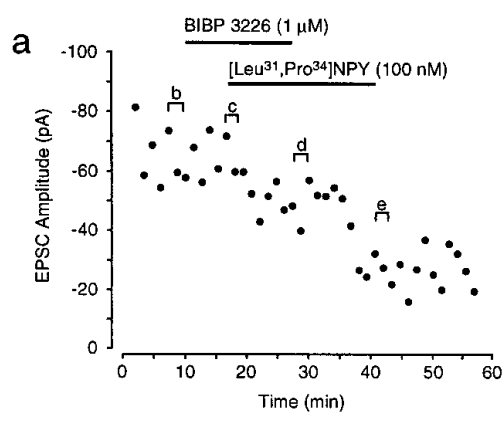

b

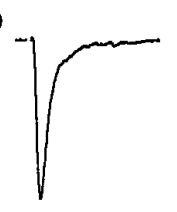

Control

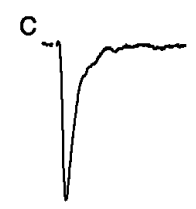

BIBP 3226
$(1 \mu \mathrm{M})$ d

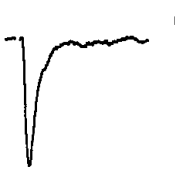

BIBP $3226(1 \mu \mathrm{M})+$ (100 nM) Leu $^{31}$, Pro $^{34}$ NPY

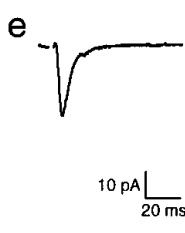
(100 nM)
Leu ${ }^{31}, \mathrm{Pro}^{34} \mathrm{NPY}$

Figure 9. BIBP 3226 was capable of blocking some, but not all, of the effects produced by $\left[\mathrm{Leu}^{31}, \mathrm{Pro}^{34}\right]$ NPY. $A, 1 \mu \mathrm{M}$ BIBP 3226 completely blocked the actions of $100 \mathrm{nM}\left[\mathrm{Leu}^{31}, \mathrm{Pro}^{34}\right] \mathrm{NPY}$. However, after washout of BIBP 3226, there was a reduction in the amplitude of the evoked EPSC. $B$, BIBP 3226 blocked a portion of the response mediated by $\left[\mathrm{Leu}^{31}, \mathrm{Pro}^{34}\right] \mathrm{NPY}$. Application of $\left[\mathrm{Leu}^{31}, \mathrm{Pro}^{34}\right] \mathrm{NPY}$ in the presence of BIBP 3226 resulted in a notable $(20 \%)$ reduction in the amplitude of the EPSC. After washout of BIBP 3226 from the slice, there was a further reduction in the EPSC amplitude. For both $A$ and $B, a$ represents the time course of the effects of $\left[\mathrm{Leu}^{31}, \mathrm{Pro}^{34}\right] \mathrm{NPY}$ in the presence and absence of BIBP 3226, whereas $b-e$ are averaged EPSCs taken from the respective cell in control conditions (b), in the presence of BIBP 3226 (c), in the presence of BIBP 3226 and $\left[\mathrm{Leu}^{31}, \mathrm{Pro}^{34}\right] \mathrm{NPY}(d)$, and in the presence of $\left[\mathrm{Leu}^{31}, \mathrm{Pro}^{34}\right] \mathrm{NPY}$ only, after washout of BIBP $3226(e)$.

observations that $\left[\mathrm{Leu}^{31}, \mathrm{Pro}^{34}\right] \mathrm{NPY}$ reduced the frequency of mEPSCs in the presence of TTX also suggests that some additional site of action might be involved. Similar types of effects have been observed in other instances of presynaptic inhibition (e.g., Scholz and Miller, 1992; van den Pol et al., 1996) and may be indicative of neurotransmitter acting directly on the release apparatus or a similar site.

It appears that more than one type of NPY receptor can mediate suppression of the EPSC (Chen and van den Pol, 1996). The response is produced by NPY and $\left[\mathrm{Leu}^{31}\right.$, Pro $\left.{ }^{34}\right] \mathrm{NPY}$ and can be blocked by BIBP 3226 in some instances, indicating the involvement of a Y1 receptor in at least some of the responses. BIBP 3226, however, could not completely prevent the effects of $\left[\mathrm{Leu}^{31}, \mathrm{Pro}^{34}\right] \mathrm{NPY}$ in many instances, implying the participation of other NPY receptor subtypes as well. The consistent effects of PYY do not support the view that Y3 receptors are involved. It is interesting to note, however, that $\left[\mathrm{D}-\operatorname{Trp}^{32}\right] \mathrm{NPY}$ produced suppression of the EPSC. This compound was described originally as an NPY antagonist (Balasubramamiam et al., 1994); however it has been shown recently to be an effective agonist at the rat Y5 receptor (Gerald et al., 1996) and furthermore produces hyperphagic effects (Gerald et al., 1996; Matos et al., 1996). Interestingly, NPY, PYY, and $\left[\mathrm{Leu}^{31}, \mathrm{Pro}^{34}\right]$ NPY are all effective agonists at the Y5 receptor, and BIBP 3226 does not act as an antagonist. Additionally, Y5 receptor mRNA was found within the arcuate nucleus (Gerald et al., 1996). These observations therefore suggest a role for the Y5 receptor, in addition to the Y1 receptor, in the suppression of synaptic transmission within the arcuate nucleus. Because of the recent description of so many new subtypes of NPY receptors, it is difficult to make definitive conclusions as to which of these subtypes mediate the inhibitory effects on synaptic transmission. Nevertheless, it is clear that the Y1 and at least one other subtype of NPY receptor are involved. It is interesting to note that an autoreceptor role for Y1 receptors in the arcuate could explain why antisense inhibition of this receptor produces a "paradoxical" increase in feeding behavior (Heilig, 1995).

In conclusion, we have demonstrated the presence of NPY receptor-mediated short- and long-term synaptic modulation within the arcuate nucleus. It appears that NPY inhibits the release of glutamate and GABA within the arcuate nucleus and may additionally regulate its own release. These effects have interesting implications for the reported central actions of NPY. Both types of effects may normally be active in regulating synaptic transmission and may represent mechanisms by which feeding and other behaviors are regulated.

\section{REFERENCES}

Balasubramaniam A, Sheriff S, Johnson ME, Prabhakaran M, Huang Y, Fischer JE, Chance WT (1994) (D-Trp ${ }^{32}$ ) - neuropeptide Y: a competitive antagonist of NPY in rat hypothalamus. J Med Chem 37:811-815.

Bard JA, Walker MW, Branchek TA, Weinshank RL (1995) Cloning and functional expression of a human Y4 subtype receptor for pancreatic polypeptide, Neuropeptide Y and Peptide YY. J Biol Chem 270: 26762-26765.

Bleakman D, Harrison NL, Colmers WF, Miller RJ (1993) Investigations into neuropeptide $\mathrm{Y}$ mediated presynaptic inhibition in cultured hippocampal neurons of the rat. Br J Pharmacol 107:334-340.

Brown NA, McAllister G, Weinberg D, Milligan G, Seabrook GR (1995) Involvement of $\mathrm{G}$ protein $\alpha_{\mathrm{i} 1}$ subunits in activation of $\mathrm{G}$ protein gated inward rectifying $\mathrm{K}$ channels (GIRK1) by human NPY1 receptors. Br J Pharmacol 116:2346-2348.

Chen G, van den Pol AN (1996) Multiple NPY receptors coexist in preand postsynaptic sites: inhibition of GABA release in isolated selfinnervating SCN neurons. J Neurosci 16:7711-7724.

Colmers WF, Bleakman D (1994) Effects of neuropeptide Y on the electrical properties of neurons. Trends Neurosci 17:373-379.

Colmers WF, Wahlestedt C (1993) The biology of Neuropeptide Y and related peptides. Totowa NJ: Humana. 
Colmers WF, Lukowiak K, Pittman QJ (1988) Neuropeptide Y action in the rat hippocampal slice: site and mechanism of presynaptic inhibition. J Neurosci 8:3827-3837.

Doods HN, Wienen W, Entzeroth M, Rudolf K, Eberlein W, Engel W, Wieland HA (1995) Pharmacological characterization of the selective nonpeptide neuropeptide Y Y1 receptor antagonist BIBP 3226. J Pharmacol Exp Ther 275:136-142.

Edwards FA, Konnerth A, Sakmann B, Takahashi T (1989) A thin slice preparation for patch clamp recording from neurons of the mammalian central nervous system. Pflügers Arch 414:600-612.

Erickson JC, Clegg KE, Palmiter RD (1996a) Sensitivity to leptin and susceptibility to seizures of mice lacking neuropeptide Y. Nature 381:415-418.

Erickson JC, Hollopeter G, Palmiter RD (1996b) Attenuation of the obesity syndrome of ob/ob mice by the loss of Neuropeptide Y. Science 274:1704-1707.

Foucart S, Bleakman D, Bindokas VP, Miller RJ (1993) Neuropeptide Y and pancreatic polypeptide reduce calcium currents in acutely dissociated neurons from adult rat superior cervical ganglia. J Pharmacol Exp Ther 265:903-909.

Gerald C, Walker MW, Criscione BH, Smith KE, Vayesse P, Durkin MM, Laz TM, Linemeyer DL, Schaffhauser AO, Whitebread S, Hofbauer KG, Taber RI, Branchek TA, Weinshank RL (1996) An receptor subtype involved in neuropeptide $\mathrm{Y}$ induced food intake. Nature 382:156-159.

Gerald C, Walker MW, Vaysse PJJ, He C, Branchek TA, Weinshank RL (1995) Expression cloning and pharmacological characterization of a human hippocampal neuropeptide Y/Peptide YY Y2 receptor subtype. J Biol Chem 270:26758-26761.

Glaum SR, Alford S, Rossi DJ, Collingridge GL, Slater NT (1994) Whole cell patch recording with simultaneous measurement of intracellular calcium concentration in mammalian brain slices in vitro. Methods Neurosci 19:340-358.

Glaum SR, Hara M, Bindokas VP, Lee CC, Polonsky KS, Bell GI, Miller RJ (1996) Leptin, the obese gene product, rapidly modulates synaptic transmission in the hypothalamus. Mol Pharmacol 50:230-235.

Grundemar L, Hakanson R (1994) Neuropeptide Y effector systems: perspectives for drug development. Trends Pharmacol Sci 15:153-159.

Grundemar L, Wahlestedt C, Reis DJ (1991a) Long lasting inhibition of the cardiovascular responses to glutamate and the baroreceptor reflex elicited by neuropeptide Y injected into the nucleus of the solitary tract. Neurosci Lett 122:135-139.

Grundemar L, Wahlestedt C, Reis DJ (1991b) Neuropeptide Y acts at an atypical receptor to evoke cardiovascular depression and to inhibit glutamate responsiveness in the brainstem. J Pharmacol Exp Ther 258:633-638.

Hamill OP, Marty A, Neher E, Sakmann B, Sigworth FJ (1981) Improved patch-clamp techniques for high resolution current recording from cells and cell-free membrane patches. Pflügers Arch 391:85-100.

Heilig M (1995) Antisense inhibition of neuropeptide (NPY) - Y1 receptor expression blocks the anxiolytic - like action of NPY in amygdala and paradoxically increases feeding. Regul Pept 59:201-205.

Hendry SHC (1993) Organization of Neuropeptide Y neurons in the mammalian central nervous system. In: the biology of neuropeptide $Y$ and related peptides. (Colmers WF, Wahlestedt C, eds), pp 65-157. Totowa, NJ: Humana.

Herzog H, Hort YJ, Ball HJ, Hayes G, Shine J, Selbie LA (1992) Cloned human neuropeptide $\mathrm{Y}$ receptor couples to two different second messenger systems. Proc Natl Acad Sci USA 89:5794-5798.

$\mathrm{Hu}$ Y, Bloomquist BT, Cornfield LJ, DeCarr LB, Flores-Riveros JR, Friedman L, Jiang P, Lewis-Higgins L, Sadlowski Y, Schaefer J, Velazquez N, McCaleb ML (1996) Identification of a novel hypothalamic neuropeptide Y receptor associated with feeding behaviour. J Biol Chem 271:26315-26319.

Huhman K, Albers H (1994) Neuropeptide Y microinjected into the suprachiasmatic region phase shifts circadian rhythms in constant darkness. Peptides 8:1475-1478.

Kalra SP, Kalra PS (1996) Is neuropeptide Y a naturally occurring appetite transducer? Curr Opin Endocrinol Diabetes 3:157-163.

Larhammer D (1996) Evolution of neuropeptide Y, peptide YY and pancreatic polypeptide. Regul Pept 62:1-11.
Matos FF, Guss V, Korpinen C (1996) Effects of neuropeptide Y (NPY) and (D-Trp $\left.{ }^{32}\right)$-NPY on monoamine and metabolites levels in dialysates from rat hypothalamus during feeding behavior. Neuropeptides 30:391-398.

McQuiston AR, Colmers WF (1996) Neuropeptide Y2 receptors inhibit the frequency of spontaneous but not miniature EPSC's in CA3 pyramidal cells of the rat hippocampus. J Neurophysiol 76:3159-3168.

McQuiston AR, Petrozzino JJ, Connor JA, Colmers WF (1996) Neuropeptide $\mathrm{Y} 1$ receptors inhibit $\mathrm{N}$ type calcium currents and reduce transient calcium increases in rat dentate granule cells. J Neurosci 166:1422-1429.

Meister B, Ceccatelli S, Hokfelt T, Anden NE, Anden M, Theodorsson E (1989) Neurotransmitters, neuropeptides, and binding sites in the rat mediobasal hypothalamus: effects of monosodium glutamate (MSG) lesions. Exp Brain Res 76:343-368.

Miller RJ, Bell GI (1996) JAK/STAT eats the fat. Trends Neurosci 19:159-161.

Obrietan K, van den Pol A (1996) Neuropeptide Y depresses GABAmediated calcium transients in developing suprachiasmatic nucleus neurons: a novel form of calcium long-term depression. J Neurosci 16:3521-3533.

Perney TM, Miller RJ (1989) Two different G proteins mediate Neuropeptide $\mathrm{Y}$ and bradykinin stimulated phospholipid breakdown in cultured rat sensory neurons. J Biol Chem 264:7317-7327.

Rimland JM, Seward EP, Humbert Y, Ratti W, Trist DG, North RA (1996) Co-expression with potassium channel subunits used to clone the Y2 receptor for Neuropeptide Y. Mol Pharmacol 49:387-390.

Rudolf K, Eberlein W, Engel W, Wieland A, Willim KD, Entzeroth M, Wienen W, Beck-Sickinger AG, Doods HN (1994) The first highly potent and selective non-peptide neuropeptide Y Y1 receptor antagonist: BIBP 3226. Eur J Pharmacol 271:R11-R13.

Scholz KP, Miller RJ (1992) Inhibition of quantal transmitter release in the absence of calcium influx by a $G$ protein-linked adenosine receptor at hippocampal synapses. Neuron 8:1139-1150.

Schreibmayer W, Dessauer CW, Vorobiov D, Gilman AG, Lester HA, Davidson N, Dascal N (1996) Inhibition of an inwardly rectifying $\mathrm{K}^{+}$ channel by G-protein alpha-subunits. Nature 380:624-627.

Shigeri S, Fujimoto M (1992) Two different signal transductions of neuropeptide Y1 receptor in SK-N-MC cells. Biochem Biophys Res Commun 187:1565-1571.

Stanley BG (1993) Neuropeptide Y in multiple hypothalamic sites controls eating behaviour, endocrine and autonomic systems for body energy balance. In: The biology of neuropeptide $\mathrm{Y}$ and related peptides. (Colmers WF, Wahlestedt C, eds), pp 457-509. Totowa NJ: Humana.

Stephens TW, Basinski M, Bristow PK, Bue-Vallesky JM, Burgett SG, Craft L, Hale J, Hoffmann J, Hsiung HM, Kriauciunas A, MacKellar W, Rosteck PR, Schoner B, Smith D, Tinsley FC, Zhang XY, Helman M (1995) The role of neuropeptide $Y$ in the antiobesity action of the obese gene product. Nature 377:530-532.

Sun L, Philipson LH, Miller RJ (1996) Regulation of G-protein linked K and Ca channels by a family of neuropeptide Y receptors. Soc Neurosci Abstr 22:1552.

Toth PT, Bindokas D, Bleakman WF, Colmers WF, Miller RJ (1993) Presynaptic inhibition by neuropeptide $\mathrm{Y}$ is mediated by reduced $\mathrm{Ca}$ influx at sympathetic nerve terminals. Nature 364:635-639.

van den Pol AN, Obietan K, Chen G, Belousov AB (1996) Neuropeptide Y-mediated long-term depression of excitatory activity in suprachiasmatic nucleus neurons. J Neurosci 16:5883-5895.

Weinberg DH, Sirinathsinghji DJS, Tan CP, Shiao LL, Morin N, Rigby MR, Heavens RH, Rapoport DR, Bayne ML, Cascieri MA, Strader CD, Linemeyer DL, MacNeil DJ (1996) Cloning and expression of a novel neuropeptide Y receptor. J Biol Chem 271:16435-16438.

Wieland HA, Willim KD, Entzeroth M, Wienen W, Rudolf K, Eberlein W, Engel W, Doods HN (1995) Subtype selectivity and antagonistic profile of the nonpeptide Y1 receptor antagonist BIBP 3226. J Pharmacol Exp Ther 275:143-149.

Zidichouski JA, Chen H, Smith PA (1990) Neuropeptide Y activates inwardly rectifying $\mathrm{K}$ channels in $\mathrm{C}$ cells of amphibian sympathetic ganglia. Neurosci Lett 117:123-128. 